Standards Deviation 



\title{
Standards Deviation
}

\author{
HOW SCHOOLS \\ MISUNDERSTAND EDUCATION \\ POLICY
}

James P. Spillane

Harvard University Press

Cambridge, Massachusetts

London, England

2004 
Copyright $\odot 2004$ by the President and Fellows of Harvard College All rights reserved

Printed in the United States of America

Library of Congress Cataloging-in-Publication Data

Spillane, James P.

Standards deviation : how schools misunderstand education policy / James P. Spillane. p. $\mathrm{cm}$.

Includes bibliographical references and index.

ISBN 0-674-01323-9 (cloth : alk. paper)

1. Education and state-United States. 2. Education-Standards-United States.

I. Title.

LC89.S54 2004

379.73-dc22 2003067510 
In memory of my father, Philip Spillane (1927-1993), who taught me the value of having an opinion but keeping an open mind

A N D

To my mother, who continues to model the power of persistence 
